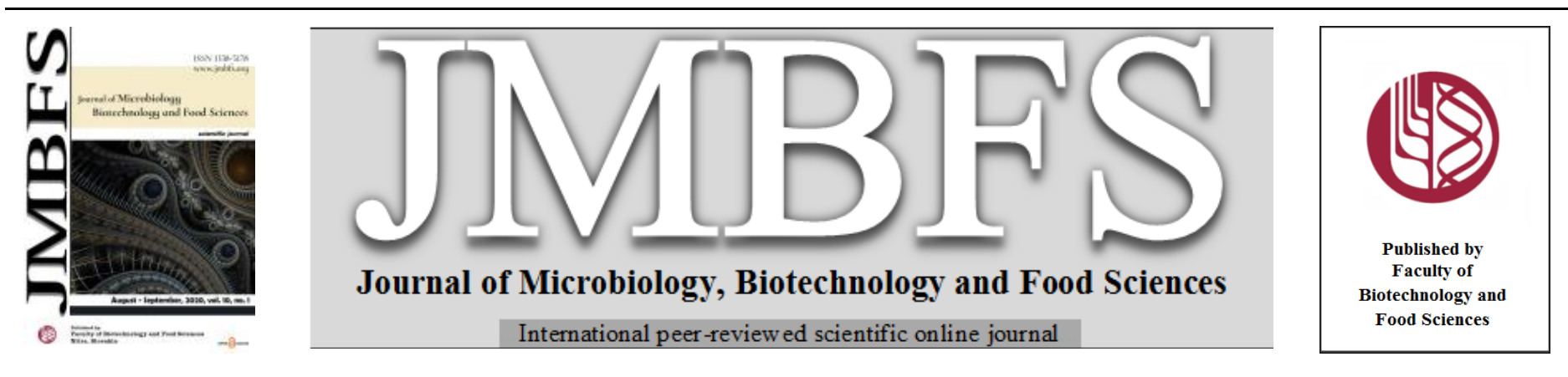

\title{
THE EFFECT OF CYST NEMATODE (GLOBODERA ROSTOCHIENSIS) ISOLATE DDH1 ON GENE EXPRESSION IN SYSTEMIC LEAVES OF POTATO PLANT
}

\author{
Dina H. Elkobrosy ${ }^{l}$, Dalia G. Aseel ${ }^{l}$, Nader R. Abdelsalam ${ }^{2}$, Mohamed A. El-Saedy $^{3}$, Saad Shama ${ }^{2}$, Elsayed E. Hafez ${ }^{l}$
}

Address(es): Ph.D. Dalia Aseel,

${ }^{1}$ Plant Protection and Biomolecular Diagnosis Department, Arid Lands Cultivation Research Institute, City of Scientific Research and Technological Applications, New Borg El-Arab City, 21934 Alexandria, Egypt.

${ }^{2}$ Agricultural Botany Department, Faculty of Agriculture (Saba Basha), Alexandria University, 21531 Alexandria, Egypt.

${ }^{3}$ Plant Pathology Department, Faculty of Agriculture (Elshatby), Alexandria University, 21545 Alexandria, Egypt.

*Corresponding author: daliagamil52@gmail.com

doi: 10.15414/jmbfs.2020.10.1.93-97

ARTICLE INFO

Received 26. 3. 2019

Revised 12.3. 2020

Accepted 23. 3. 2020

Published 1. 8. 2020

Regular article

open ${ }_{\text {Aackess }}$

\begin{abstract}
Globodera rostochiensis (Cyst nematode-DDH1) is a major pathogen of potato, this type of nematode was recently reported in Egypt in 2017 as a serious plant pathogen especially in Alexandria and El-Behera governorates. This study aimed to identify this species $(G$. rostochiensis) on the molecular level in addition to examine the plant-cyst nematode interaction. The results of ITS-PCR showed two bands with molecular sizes $238 \mathrm{bp}$ and $370 \mathrm{bp}$. The small band is identified as internal band for the large one. The sequence analysis was conducted on 238 bp amplicon and the results obtained confirm that the obtained DNA sequence belong cyst nematodes ( $G$. rostochiensis) with similarity 77\%. The constructed phylogenetic tree based on the DNA nucleotide sequence showed close relationship with a Japanese G. rostochiensis (AB207271). The functional transcriptome of the infected and non-infected potato plants was analyzed using Differential Display- PCR technique and about 57 up regulated and 22 down regulated genes. Seven genes ( 2 downregulated and 5 upregulated) were chosen at random and sequenced. The nucleotide sequences observed that the two down regulated genes were; Chitinase domain containing protein 1 and $\mathrm{N}$-like putative resistance protein. Whereas, the five up regulated genes were; Glucan endo 1,3 beta glucosidase A precursor, STS 14 protein gene, Phytoalexin deficient 4-1 protein gene, PEN1 gene and Linoleate 13S lipoxigenase 2-1, chloroplastic like, respectively. We can concluded that the regulation changes occurred for some pathogen related genes in systemiclly acquired immunity of infected potato plant compared with control were the main observation. Moreover, the cyst nematode could be able to suppressd some of plant defense system genes and inducing another in the same time.
\end{abstract}

Keywords: Cyst nematode, G. rostochiensis, ITS-PCR, Phylogenetic tree, DD-PCR, PRs gene, Sequence

\section{INTRODUCTION}

The potato cyst nematode (Globodera spp.) is a major pathogen of potato plants (Solanum tuberosum), which contributes to the localized dedifferentiation of a restricted number of host cells into a specific feeding site called the syncytium (Gurr et al., 1991). The genus of cyst nematode (Globodera) has been reported in Egypt. Globodera rostochiensis was first found in 2017 on potato plants, in three governorates of Egypt; Alexandria, El-Behera and Sohag (Ibrahim et al. 2017). The parasitic root cyst nematode spends a great portion of their life cycles embedded in the roots of a host plant and thus exposed to a various of plant defence responses, consequently, decrease for both quality and crop yield in infected fields (Sattarzadeh et al., 2006). Other research by (Shepherd 1986) assumed that the traditional methods which depended on phenotypic characteristics and counting the egg or juvenile, the approach of hatching tests to determine cyst nematode infestation levels became time-consuming and also require viability assessments as the use of vital stains.

PCR assay can supply good estimate of potato cyst nematode and variation of DNA nucleotides in ITS regions of the ribosomal DNA used to detect numerous nematode species and that difference was determinate by amplify the ITS regions using conserved PCR primers (Fleming et al., 1998).

Pathogenesis-related proteins (PR) were exposed to pathological and other stressrelated situations in plants as one of the protein inducers. While PR protein function is not clearly understood in plants, it is produced in large quantities for both resistant reactions and hypersensitive (Rahimi et al., 1993). The prime local response of plant for resistance against a broad spectrum of pathogens is systemic acquired resistance (SAR) (Dong 2001 and Me'traux 2001). Thus, SAR is one of the defense mechanisms against pathogen attacks in plants, in distal tissues, this influence appear as resistance and protection (Alférez et al., 2008).

The interaction between plant and pathogen causes major changes in plant gene expression. Signaling pathways such as hypersensitive reaction or induction or suppression of target genes are control by transcriptional factors, among the targets of these pathways, its control of response genes expression, including those encoding PRs and wound responses (Dellagi et al., 2000). After root infection with cyst nematode, some changes occur of gene expression in potato leaves included induction of pathogenesis related proteins (Hammond et al., 1989). Plant genes were extracted and their up regulated genes after nematode infection has been expressed using molecular techniques (Niebel $\boldsymbol{e t}$ al, 1994 and Sijmons et al., 1994).

The objectives of this investigation were; the expression detection of pathogen related genes which induced in the systemic acquired resistance of potato plants upon cyst nematode infection. Moreover, molecular identification for both cyst isolates and the genes which induced as result of plant-nematode interactions.

\section{MATERIAL AND METHODS}

Cyst nematode isolation and propagation

Approximately, $1.5 \mathrm{~kg}$ of sandy clay soil samples infected with cyst nematodes were collected from the soil layers at $20-40 \mathrm{~cm}$ depth and then placed in a plastic bags were labelled with date and soil type. These samples were collected from El-Beheira Governorate (El-Nubaria). Cyst nematodes were extracted from the soil using a pair of sieves (250 and 840 mesh size) (Shepherd 1985) and then stored in eppendorf tubes at room temperature. These cyst nematodes were propagated on the roots potato plants (Spunta cultivar under greenhouse conditions $27^{\circ} \mathrm{C}$; 20-22 L: D photoperiod). Subsequently, the propagated cysts were isolated after 10 to 12 weeks' post inoculated the potato plant with the examined nematode according to (Cotton et al., 2014). 
Identification of cyst nematode using ITS gene by specific PCR, sequencing and phylogentic analysis

Total genomic DNA was extracted from the cyst nematode samples using Genomic DNA extraction kit (iNtRoNBiotechnology, USA). The genomic DNA was subjected to PCR amplification using the universal primers (ITS1:5 TCCGTAGGTGAACCTGCGG- 3 and ITS4:5 -TCCTCCGCTTATTGATATG`3) (White et al., 1990). The PCR mixture reaction including; $12.5 \mu \mathrm{L}$ PCR master mix (Applied biotechnology, Egypt), $1 \mu \mathrm{L}$ of each ITS-primers $10 \mathrm{pmol} / \mu \mathrm{L}$, and up to volum $25 \mu \mathrm{L}$ from mile $\mathrm{Q}$ water. PCR reactions were carried out in a thermal cycling (Gene Amp 9700, USA) with an initial denaturation step for 5 min at $94^{\circ} \mathrm{C}$, followed with 35 cycles each for 1 min at $94^{\circ} \mathrm{C}$, annealing temperature at $55^{\circ} \mathrm{C}$ for $1 \mathrm{~min}$, elongation at $72^{\circ} \mathrm{C}$ for $1 \mathrm{~min}$ and final elongation at $72^{\circ} \mathrm{C}$ for $5 \mathrm{~min}$, then the samples were held at $4^{\circ} \mathrm{C}$. The product of PCR amplification was loaded into $2 \%$ agarose gel, stained with ethidium bromide an separated by electrophoresis as described by (Shaikhaldein $\boldsymbol{e t}$ al., 2018). The PCR fragment was purified using the PCR clean up column kit (Maxim biotech INC, USA) and the purified PCR product was subjected to DNA sequencing by Sigma (Macrogene com, Korea). The obtained DNA nucleotide sequence was submitted to National Center for Biotechnology Information (NCBI) and the sequence alignment was compared with other cyst nematode ITS genes listed in the GenBank database. Phylogenetic tree was carried out using MEGA 4.0 program (Tamura et al., 2007).

\section{Potato growth and nematode infection assay}

Healthy potato tubers of Spunta cultivar were selected, surface sterilized with $75 \%$ ethanol for $5 \mathrm{~min}$, followed by $10 \mathrm{~min}$ in $2.5 \%$ sodium hypochlorite and finally, the tubers were rinsed three times with sterile water. The sterile tubers were cultivated singly in $25 \mathrm{~cm}$ plastic pots in (3:1 mixture of autoclaved loam and sand) without fertilizers. Potato plants cultivated at greenhouse under conditions $\left(27^{\circ} \mathrm{C} ; 20-22 \mathrm{~L}\right.$ : D photoperiod) were inoculated through four weeks after planting. The plants were irrigated every two days. Cysts were used in inoculation approximately, 60 cysts of G. rostochiensis per pot and pots were irrigated with tap water. Cyst insertion was performed into the soil near to the roots (Andreas et al., 1995). The leaves of inoculated potato plants were collected on intervals after the inoculation; $12 \mathrm{~h}, 24 \mathrm{~h}, 48 \mathrm{hr}, 7 \mathrm{~d}, 14 \mathrm{~d}, 21 \mathrm{~d}, 28 \mathrm{~d}$, $35 \mathrm{~d}, 42 \mathrm{~d}$ and 49 days post infection (dpi).

\section{Total RNA extraction and reverse transcription-PCR}

Total RNAs were extracted from infected and uninfected potato leaves using (TRIzol, Invitrogen, USA) according to the manufacture procedures. The RTPCR of mRNA was converted to cDNA and the components of reaction were performed in total volume $25 \mu \mathrm{l}$ for each reaction mixture consists; $4 \mu \mathrm{l}$ of $2 \mathrm{mg} / \mathrm{ml}$ RNA, $1 \mu \mathrm{l}$ of $10 \mathrm{pmol}$ of Oligo-dT primer (Clontech INC, USA), $2.5 \mu \mathrm{l}$ of $5 \mathrm{x}$ reaction buffer (Promega, USA), $2.5 \mu 1$ of $2 \mathrm{mM}$ dNTPs (SibEnzyme, Russia), $0.2 \mu 1$ of 5 U AMV Reverse Transcriptase enzyme (Promega, USA) and $14.8 \mu 1$ sterile distilled water. This reaction was performed in a thermal cycler programmed at $42^{\circ} \mathrm{C}$ for 1 hour, and then the enzyme was inactivated at $72^{\circ} \mathrm{C}$ for $10 \mathrm{~min}$ and the final step at $4^{\circ} \mathrm{C}$ for $10 \mathrm{~min}$.

Differential display PCR (DD-PCR) and selected of the up-down regulated genes for both infected and healthy potato plants

Ten arbitrary primers were used in the Differential Display Analysis, seven of these primers were related to pathogenesis related proteins such as endogluconase (PR1), chitinase (PR3), chitin binding protein (PR4), peroxidase (PR9), polyphenol oxidase (PPO) as described by (Rashad et al., 2018), phenylalanine ammonia lyase (PAL) and the three other arbitrary primers were (RAPD5, RAPD10 and RAPD7). The sequences of these primers were illustrated in (Table 1). The reaction mixture of Differential Display - PCR amplification was carried out in total volume $25 \mu \mathrm{l}$ for each reaction mixture contains; $4 \mu \mathrm{l}$ cDNA template, $4 \mu 1$ primer, $12.5 \mu 1$ Master mix DNA polymerase (Applied Biotechnology, Egypt) and $4.5 \mu 1$ distilled sterile water in thermal cycler PCR program with an initial denaturation step for $2 \mathrm{~min}$ at $95^{\circ} \mathrm{C}$ for one cycle, followed with 40 cycles of $1 \mathrm{~min}$ at $94^{\circ} \mathrm{C}, 1 \mathrm{~min}$ at $30^{\circ} \mathrm{C}$ for annealing, the extension was performed for 1 $\min$ at $72^{\circ} \mathrm{C}$ and the final extension was carried out at $72^{\circ} \mathrm{C}$ for $5 \mathrm{~min}$. The final step kept the product at $4^{\circ} \mathrm{C}$.

Nucleotide sequence and phylogentic analysis of randomly selected genes for both up or down regulated

Seven genes of different expressed up and down regulated genes were selected, purified and sequenced according to (Aseel et al., 2019).

RESULTS
Identification of cyst nematode using ITS gene, sequencing and phylogentic analysis

The PCR product of ITS regions for Cyst nematode-DDH1 isolate showed two different amplicons $238 \mathrm{bp}$ and $370 \mathrm{bp}$ as shown in (Fig. 1A). The DNA nucleotide sequence of obtained the $238 \mathrm{bp}$ band was aligned with the other published Globodera rostochiensis genes available in GenBank database (http://www.ncbi.nlm.nih.gov). The results confirm that the obtained sequence belong cyst nematode Globodera rostochiensis. Moreover, dependent on the result of DNA nucleotide sequence, the phylogenetic tree was generated as shown in (Fig. 1B). The constructed phylogenetic tree of Globodera rostochiensis was divided into two main clusters; one of them includes the Egyptian isolate of $G$. rostochiensisa combined with Japanese isolate (AB207271). Additionally, the similarity between the Egyptian and the Japanese isolates was $77 \%$.

Table 1 The arbitrary pathogen related protein primers and RAPD primers used in DD-PCR

\begin{tabular}{llc}
\hline \multicolumn{1}{c}{ Primers } & Type & Sequence $\mathbf{5}^{\prime} \rightarrow \mathbf{3}^{\prime}$ \\
\hline $\begin{array}{l}\text { Endogluconase } \\
\left(\mathrm{PR}_{1}\right)\end{array}$ & Forward & TTC TTC CCT CGA AAG CTC AA \\
\hline Chitinase $\left(\mathrm{PR}_{3}\right)$ & Forward & CGG TGG TAC TCC TCC TGG ACC C \\
\cline { 2 - 3 } $\begin{array}{l}\text { Chitin Binding } \\
\text { Protein }\left(\mathrm{PR}_{4}\right)\end{array}$ & Reverse & CGG CGC CAC GGT CGG CGT CTG A \\
\hline $\begin{array}{l}\text { Peroxidase } \\
\left(\text { POX) }\left(\mathrm{PR}_{9}\right)\right.\end{array}$ & Forward & GCTTTGTCAGGGGTTGTGAT \\
\hline $\begin{array}{l}\text { Polyphenol } \\
\text { oxidase }(\mathrm{PPO})\end{array}$ & Reverse & CCATCTATGGAACGGGAAGA \\
\hline $\begin{array}{l}\text { Phenylalanine } \\
\text { AmmoniaLyase } \\
(\text { PAL })\end{array}$ & Forward & CATGCTCTTGATGAGGCGTA \\
\hline RAPD 5 & Forward & CAGGGGACGA \\
\hline RAPD 10 & Forward & GAGAGCCAAC \\
\hline RAPD 7 & Forward & ACCGCCGAAG \\
\hline
\end{tabular}

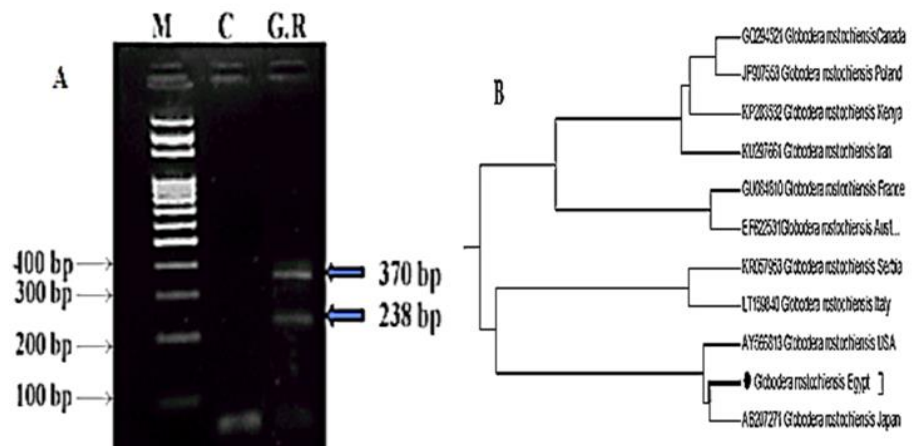

Figure 1 Amplified PCR products from cyst nematode G. rostochiensis generated by the ITS primers, where M: $1.5 \mathrm{kbp}$ DNA marker, lane C (negative control) and lane G.R (Globodera rostochiensis) PCR amplicons were 238 bp and 370 bp. B) Phylogenetic tree of Globodera rostochiensisEgyptian isolate with the other sequence published of Globodera rostochiensisalignment into GenBank.

Up and down regulation genes using DD-PCR analysis demonstrated a role of defense against pathogens

The DD-PCR results revealed that, the leaves of infected potato plants which collected on intervals after the inoculation; $12 \mathrm{~h}, 24 \mathrm{~h}, 48 \mathrm{hr}, 7 \mathrm{~d}, 14 \mathrm{~d}, 21 \mathrm{~d}, 28 \mathrm{~d}$ $35 \mathrm{~d}, 42 \mathrm{~d}$ and 49 days post infection (dpi). The general observation revealed that several common bands between control and infected potato plants. On the other hands, the presence of some bands in the infected plants those were absent in the control and vice versa. Results generated by PR3r primer showed only one up regulated band with molecular size $611 \mathrm{bp}$ (12hr after infection), this band was down regulated after $24 \mathrm{hr}$ and $48 \mathrm{hr}$ post infection when compared with the control (Fig. 2 a). While, differential expression was observed in infected plants with primer PR3f and the results showed unique band with molecular size 590 bp after 35 days as shown in (Fig. 2 b) furthermore, a band of 900 bp in control plants has been disappeared completely (down regulated) just the infection occurred.

Whereas, there was common band was observed after 14 days post infection with molecular size $1500 \mathrm{bp}$ as a result of early infection with cyst nematode. The gene expression by DD-PCR using PPO primer represented 322 bp band with high intensity in the infected sample 28 days post infection as illustrated in (Fig. 2 c). DD-PCR profile using PR9 primer represented similar bands in the same lengths when compared with control, while, these bands are differed in their 
intensity during intervals of infection. Accordingly, genes induction of infected potato plants was accomplished as illustrated in (Fig. 2 d). High gene expression was noticed with infected plants after $48 \mathrm{hr}$ post infection with molecular sizes; 205 and 320 bp. As shown in (Fig. 2 e) using PAL primer, results revealed that a number of high intensive common bands between control and infected plant after $12 \mathrm{hr}$, $24 \mathrm{hr}$ and $48 \mathrm{hr}$ post infection (290 and $300 \mathrm{bp}$ ), these two bands inverted into low intensive in early infection after 7 days post infection and subsequently, gradually disappeared in the late infection from 21 days pos infection till became down regulated at 49 days post infection. The use of PR4 primer in DD-PCR was illustrated in (Fig. $2 \mathrm{f}$ ) where, there was induced band appeared in infected plants $48 \mathrm{hr}$ post infection with size $280 \mathrm{bp}$ comparing with control. Consequently, the PR1 primer, the DD-PCR products revealed different genes in infected potato plants after 28 days post infection by G. rostochiensis with molecular size 690 bp compared with control plants (Fig $2 \mathrm{~g}$ ). The induction as a result of infection, causes many alteration in gene expression regulation for both up or down with RAPD5 primer (Fig. 2 h), in contrast, only one band was observed with the control plants (295 bp, up regulated). In case of RAPD 7 primer, high gene expression was observed (up regulation) a 7 bands with molecular sizes ranged from $\approx 200-700$ bp after 12,24 and 48 hrs post infection compared with control (Fig. 2 i)

The DD-PCR amplification products of infected potatoes with nematode using RAPD10 primer (Fig 2 j), many different bands were up and down regulated genes that means, the pathogen ( $G$. rostochiensis) induced the potato plant genes, therefore the changes in gene expression has been occurred and appeared in different intensity of numerous bands with assorted DNA with molecular sizes $390 \mathrm{bp}$ and $400 \mathrm{bp}$ after $12 \mathrm{hr}$ to 7 days post infection respectively. Moreover, the negative control samples showed up regulated band with molecular size $700 \mathrm{bp}$, in addition up regulated band with molecular size 610 bp compared with control at 21 days after infection.

(a)

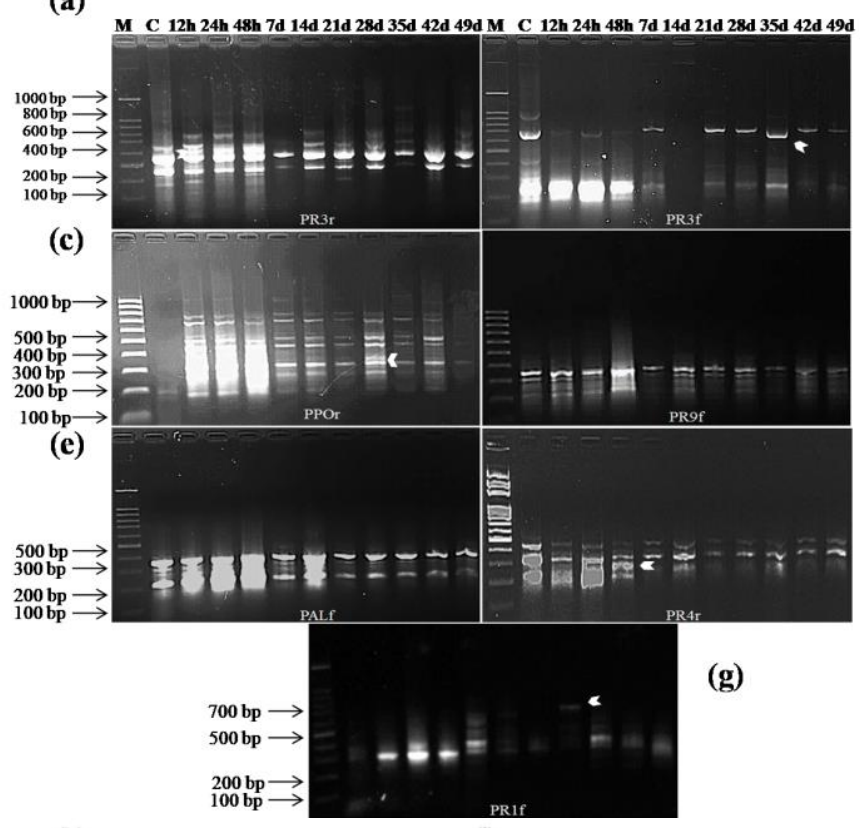

(h)

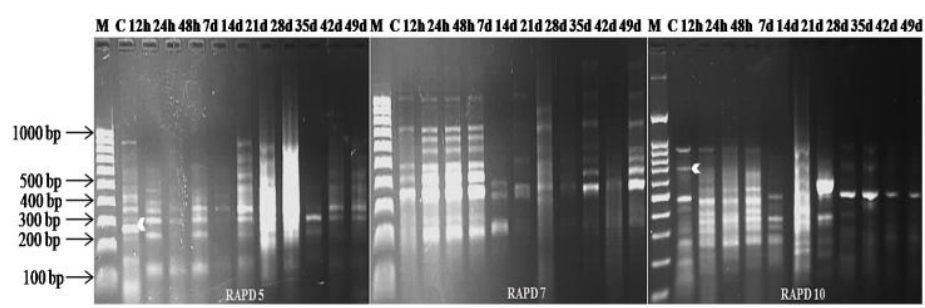

Figure 2 Up and down regulated genes of the DD-PCR using various arbitrary primers PR3r (a), PR3f (b), PPOr (c), PR9f (d), PALf (e), PR4r (f), PR1f (g), RAPD5 (h) RAPD7 (i) and RAPD10 (j) refaring to the 7 selected bands for sequencing (arrows). M; $1.5 \mathrm{Kbp}$ DNA marker, C; untreated potato plants (control), 12h; infected with $G$. rostochiensis after 12 hours, 24h; infected with $G$. rostochiensis after 24 hours, $48 \mathrm{~h}$; infected with $G$. rostochiensis after 48 hours, 7d; infected with $G$. rostochiensis after 7 days, 14d; infected with $G$. rostochiensis after 14 days, 21d; infected with $G$. rostochiensis after 21 days, $28 \mathrm{~d}$; infected with $G$. rostochiensis after 28 days, 35d; infected with $G$ rostochiensis after 35 days, $42 \mathrm{~d}$; infected with $G$. rostochiensis after 42 days and 49d; infected with $G$. rostochiensis after 49 days.

\section{Sequence and phylogentic analysis of potato pathogen related genes}

The randomly selected DD-PCR bands with molecular sizes; 690, 590, 611, 280, 322,295 and 700 bp as shown in table (2) up and down regulated genes were excised from the gel, purified and sequenced. The nucleotide sequences of these bands were aligned with the other deposited potato pathogen related genes available in the GenBank database and the results revealed that the band of 690 bp was "Glucanendo 1, 3 beta glucosidase precursor. Whereas, the band of 590 bp is Linoleate $13 \mathrm{~S}$ lipoxigenase $2-1$ but the band of 611 bp was Phytoalexin deficient 4-1 protein gene. The band of molecular size 280 bp was PEN1 gene. Whenever, the amplicon of $322 \mathrm{bp}$ is STS 14 protein gene but the band of $295 \mathrm{bp}$ was identified as Chitinase domain containing protein 1 " and finally, the $700 \mathrm{bp}$ band was identified as N-like putative resistance protein (Table 2).

The DNA neculeotide sequences of the DD-PCR selected bands was used in construction of phylogenetic tree in compared with the other related genes listed on data base Fig. (3). The collective results indicated that, the Glucanendo 1,3 beta glucosidase A was induced as consequence of cyst infection and function an active role in hydrolysing $\beta$-1,3-glucan (a major structural component of pathogen cell walls), in addition it has significant role in the defence response against cyst nematode as a plant pathogenesis-related protein. In addition, the STS 14 protein gene is considered one of plant defense gene against plant pathogen and it is closely related to STS14-like proteins expressed in Solanum tuberosum. The Phytoalexin deficient 4-1 protein gene is identified as signal pathogenesis related proteins (R-gene signaling) which regulated SA mediated resistance response ( $S$. tuberosum). The PEN1 gene its function is mediated secretory pathway in the pathogene trigger immunity against pathogen attacks. But, the Linoleate 13S lipoxigenase working as oxido-reductase activity and required for the wound-induced synthesis of jasmonic acid (JA) in leaves. Whenever, the Chitinase domain containing protein 1 had carbohydrate binding sites and was conserved very far back to organisms such as Caenorhabditis elegans. The PEN1 gene and Linoleate 13S lipoxigenase 2-1 are pathogen related genes. The $\mathrm{N}$-like putative resistance protein is disease resistance protein and protects the plant against pathogens that contain an appropriate avirulence protein via a direct or indirect interaction with this avirulence protein. That triggers a defense system which restricts the pathogen growth where, response to the presence of a foreign body or the occurrence of an injury, which result in restriction of damage to the pathogen attacked or prevention or recovery from the infection caused by the attack.

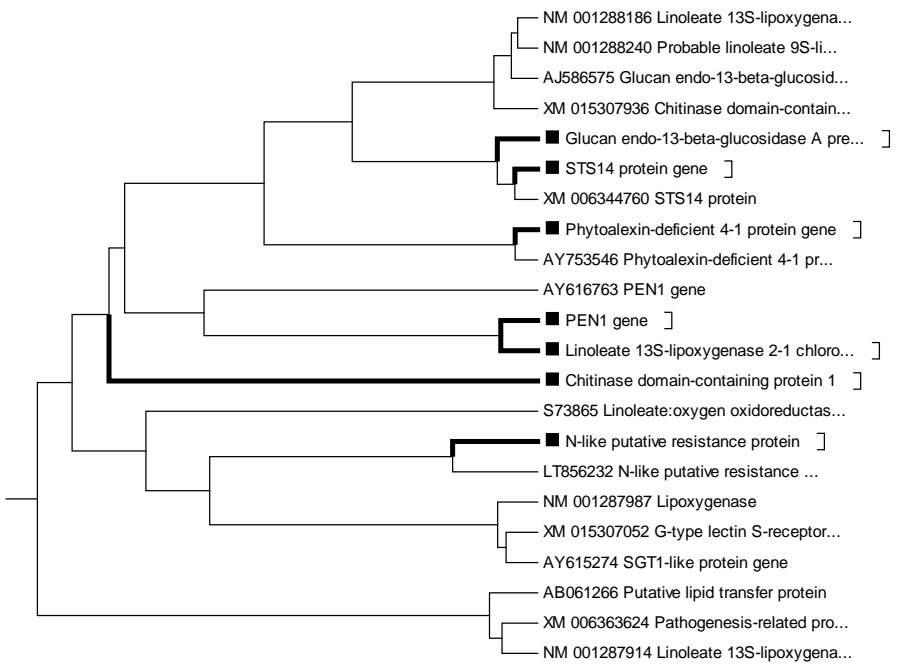

Figure 3 Phylogenetic tree of the 7 (up and down) sequenced and aligned genes with the other published defensin genes and their accession numbers based on the nucleotide sequence alignment into GenBank. The scale for the branch length was given in substitutions per site. 
Table 2 The up regulated genes induced upon Globodera rostochiensis infection and down regulated genes in the potato leaves

\begin{tabular}{|c|c|c|c|}
\hline Primer & Name of sequence aligned genes & Length (bp) & Function of genes \\
\hline $\begin{array}{l}\text { Endoglucona } \\
\text { se }\left(\mathrm{PR}_{1}\right)\end{array}$ & $\begin{array}{l}\text { Glucan endo } 1,3 \text { beta glucosidase A precursor. } \\
\text { (Up regulated gene) }\end{array}$ & 690 & $\begin{array}{l}\text { Has a vital role against pathogen attacks where, acting as a plant } \\
\text { pathogenesis related protein, and induced by pathogen infection and it } \\
\text { may hydrolysing a major structural component of pathogen cell walls } \\
\text { which called } \beta-1,3 \text {-glucan (Hamamouch } \text { et al., 2011). }\end{array}$ \\
\hline $\begin{array}{l}\text { Polyphenol } \\
\text { oxidase } \\
\text { (PPO) }\end{array}$ & $\begin{array}{l}\text { STS } 14 \text { protein gene } \\
\text { (Up regulated gene) }\end{array}$ & 322 & $\begin{array}{l}\text { Coding for a highly expressed mRNA in Solanum tuberosum explains } \\
\text { similarity to pathogenesis related PR1 proteins of tobacco, } \\
\text { Arabidopsis, barley, maize and tomato. The main function is } \\
\text { protection against pathogens (Kombrink et al., 1988). }\end{array}$ \\
\hline $\begin{array}{l}\text { Chitin } \\
\text { Binding } \\
\text { Protein }\left(\mathrm{PR}_{4}\right)\end{array}$ & $\begin{array}{l}\text { PEN1 gene } \\
\text { (Up regulated gene) }\end{array}$ & 280 & $\begin{array}{l}\text { One of important components of PTI (pathogene trigger immunity) } \\
\text { against plant microbes in plants where, it mediated secretory } \\
\text { pathway, so the main function is consider it one of defense signaling } \\
\text { genes in potato plants (Li R. Rashotte et al., 2015). }\end{array}$ \\
\hline RAPD 5 & $\begin{array}{l}\text { Chitinase domain containing protein } 1 \text { (CHID1) } \\
\text { (Down regulated gene) }\end{array}$ & 295 & $\begin{array}{l}\text { This protein was recognized to have carbohydrate binding sites, } \\
\text { which could be involved in carbohydrate catabolysis and was } \\
\text { conserved very far back to organisms such as Caenorhabditis } \\
\text { elegans. }\end{array}$ \\
\hline RAPD 10 & $\begin{array}{l}\text { N-like putative resistance protein } \\
\text { (Down regulated gene) }\end{array}$ & 700 & $\begin{array}{l}\text { Is putative disease resistance protein where, considered it structural } \\
\text { domains associated with resistance gene function in resistance } \\
\text { response of potato against pathogens. }\end{array}$ \\
\hline
\end{tabular}

\section{DISCUSSION}

Globodera rostochiensis consider one of the plant parasitic cyst nematodes; was found in three governorates of Egypt in 2017 as previously mentioned by (Ibrahim et al., 2017). It is living in the soil and attacks the roots of plants. Moreover, it is obtained its nutrition from the cytoplasm of living plant cells causes terrible crop losses especially, potato plants which consider one of great economic crop and most essential crop in Egypt. Therefore, this investigation aimed to detect and identify the systemic induced genes of infected potato plants with cyst nematode via plant-nematode interactions. The cyst nematode samples were collected, isolated, propagated and identified and the well characterized nematode was used in studying the nematode-plant interaction on the molecular level.

In the current study, the ITS PCR showed two different molecular sizes 238 and $370 \mathrm{bp}$. Similar result was obtained by PCR using G. rostochiensis specific primer and succeeded to identify $G$. rostochiensis ribosomal DNA sequence by (Fleming et al., 1998) while, they found that, the PCR product of DNA was 238 bp. At the same investigation, the PCR result amplification product of interna standard template DNA was $748 \mathrm{bp}$ according to their use of potato cyst nematode universal primer and it contradicted our result which was 370 According to (Fleming et al., 1998) they used an artificial internal control template to evaluate the quantity of target nematode DNA in a sample and thus to determine the viability and pest potential of the population. This could allow the population levels of cyst nematodes to be estimation over with species composition.

Infected potato plants with $G$. rostochiensis could differentially induce/suppressed a number of genes. DD-PCR results reflected the systemic response of plant cell according to $G$. rostochiensis infection. Subsequently, demonstration of some effective genes in plant defense against pathogens is very important. The sequence analysis identified a number of genes that putatively encode proteins that function in signal transduction during secretory pathway, control of gene expression and protect plant against pathogen attacks In this study, some genes were showed high similarity with the other pathogen related genes, these genes were differentially expressed in plant leaves and most of them were up regulated (induced by nematode infection).

Glucanendo 1,3 beta glucosidase A amplified by the PR1 primer and it was induced in the infected potato plants after 28 days post infection with $G$. rostochiensis at late infection. Conversely, some studies reported significant increasing of $\beta-1,3$-endoglucanase to a maximum at 5 days post cyst nematodes infection during the gene expression and converted into down regulated by 9 and 14 days post infection wherever, the highest levels of $\beta-1,3$-endoglucanase expression during the plant-nematode interaction, enhance parasitism of cys nematodes infection in the early stages (3-5 days post infection) (Hamamouch et al., 2012). Furthermore, (Hamamouch et al., 2011) reported increased of the expression level in Arabidopsis roots at 9 days after infection with the cyst nematode $H$. schachtii, using PR1 which considered one of the systemic acquired resistance markers. While, Beta endoglucanase is one of the important effector genes for plant infection with cyst nematode and up-regulated during the water uptake phase (Wang $\boldsymbol{e t}$ al., 1999). In addition, (Goellner et al., 2000) found increasing in the expression of this gene before hatching of Globodera tabacum eggs. Also (Duceppe et al., 2017) mentioned that, the most essential polysaccharide degrading enzymes gene for plant colonization and prepare the nematode for its infective phase through hatching of $G$.rostochiensis was beta-endoglucanases and it was up-regulated.

Linoleate 13S lipoxigenase 2-1 (chloroplastic like) amplified by PR3 forward primer (up regulated gene) induced at late stage of infection after 35 days post infection. In contrast, using PR3 revers primer matched with Phytoalexin deficient 4-1 protein gene (up regulated gene) this gene was induced at extremely early infection only after $12 \mathrm{hr}$ post infection. This gene was down regulated after $24 \mathrm{hr}$ post infection and this considered the developmental stage of plantnematode interaction.

Elevated level of induced gene was reported using PR4 primer called PEN1 gene at early infection stage (48 hr) post infection. On the contrary, (Hamamouch et al., 2011) demonstrated that, the expression level of PR 3 and PR4, which are universally used as characterization markers of defense responses, did not change in Arabidopsis roots at 9 days after infection with the cyst nematode $H$. schachtii. Identical results by (Beffa $\boldsymbol{e t}$ al., 1993 and Kombrink $\boldsymbol{e t}$ al. 1988) reported that, pathogen response gene up regulated encoded $\beta 1,3$ glucanase implicated in the pathogenesis related protein 2 (PR2) family and these enzymes assumed to degrade $\beta 1,3$ glucans in the pathogen cell walls to protect the host plant. It was reported that, the STS 14 protein gene (STS14-like proteins) first identified in the potato and highly expressed in the pistil (Van Eldik $\boldsymbol{e t}$ al., 1996). However, the function of this protein has not been characterized but suggested that, it has a protection function against nematode pathogens. On the other hand, Phytoalexin deficient 4-1 protein gene is essential regulator of salicylic acid mediated resistance responses during SA dependent pathways. Similar results by (Kumari et al., 2016) demonstrated that, PAD4 involved in upstream of SA production and signalling for basal resistance where, it enhance the induced defence against root knot nematodes in the early infection. However, it is essential regulator of the programmed cell death triggered by the Toll interleukin-1 receptor type of nucleotide binding leucine rich repeat immune receptor in response to avirulant pathogen isolates and in restricting the growth of normally virulent pathogen. Consequently, the PEN1 gene (Penetration gene) considering it one of the defense signaling genes in potato plants. Similar results indicated that, PEN1 is a member of the SNARE (soluble N-ethylmaleimide sensitive factor attachment protein receptor) family which involved proteins that 
mediate membrane fusion events (Pratelli et al., 2004) and it proposed to have a role in the trafficking of secretory vesicles to the plasma membrane that contain cargo required for penetration resistance against plant microbes Finally, Chitinase domain containing protein 1 gene was conserved very far back to organisms such as Caenorhabditis elegans. We assume that plant may produce chitinases to degrade the cell wall of the cyst.

\section{CONCLUSION}

This investigation considers the first report of characterize cyst nematode (Globodera rostochiensis) on molecular level in Egypt. Where it showed the impact of this nematode on suppers/ induce plant immune system of infected potato plants especially, responses of the defense genes in the systemic acquired resistance (SAR) of infected potato plants with the Egyptian isolate (Globodera rostochiensis).

Confilict of interest: No conflict of interest with any authors.

\section{REFERENCES}

Alférez, S.S., Mateos, B., Alvarado, R. and Sánchez, M. (2008). SAR induction in tomato plants is not effective against root-knot nematode infection, Eur J Plant Pathol., 120:417-425. http://dx.doi.org/10.1007/s10658-007-9225-6.

Andreas, N., Kurt, H., Nathalie, B., Dirk, I., Marc, V.M. and Gheysen, G. (1995) Characterization of a pathogen induced potato catalase and its systemic expression upon nematode and bacterial infection, Mol Plant Micr., int., 3:371378. http://dx.doi.org/10.1094/mpmi-8-0371.

Aseel, D.G., Mostafa, Y. Riad, S. A. and Hafez, E. E. (2019). Improvement of nitrogen use efficiency in maize using molecular and physiological approaches Symbiosis. Vol: 78, 263-274. https://doi.org/10.1007/s13199-019-00616-4.

Beffa, R.S., Neuhaus, J.M. and Meins, F. (1993). Physiological compensation in antisense transformants: specific induction of an "ersatz" glucan endo-1,3-beta glucosidase in plants infected with necrotizing viruses, PNAS USA. 19:87928796. http://dx.doi.org/10.1073/pnas.90.19.8792.

Cotton, J.A., Catherine, J.L., Laura, M.J., Taisei, K., Adam, J.R., Peter, T., Isheng, J.T., Helen, B., Vivian, B., Peter, J.A.C., Sebastian, E.A., Nancy, H. Martin, H., Sophie, M., Hardeep, N., Arnab, P., Juan, E.P.R., Magdalena, Z., Matthew, B., John, T.J., and Peter, E.U. (2014). The genome and life-stage specific transcriptomes of Globodera pallida elucidate key aspects of plant parasitism by a cyst nematode, Genome Biology. 15:43. http://dx.doi.org/10.1186/gb-2014-15-3-r43.

Dellagi, A., Heilbron, J., Avrova, A.O., Montesano, M., Palva, E.T., Stewart, H.E., Toth, I.K., Cooke, D.E.L., Lyon, G.D. and Birch, P.R.J. (2000). A potato gene encoding a WRKY-like transcription factor is induced in interactions with Erwinia carotovora subsp. Atroseptica and Phytophthora infestans and is coregulated with class I endochitinase expression, Mol. Plant Microb. Interact., 13:1092-1101. http://dx.doi.org/10.1094/MPMI.2000.13.10.1092.

Dong, X. (2001). Genetic dissection of systemic acquired resistance, Curr.Opin Plant Biol., 4:309-314. http://dx.doi.org/10.1016/s1369-5266(00)00178-3.

Duceppe, M.O., Lafond Lapalme, J., Palomares-Rius, J.E., Sabeh, M., Blok, V., Moffett, P. and Mimee, B. (2017). Analysis of survival and hatching transcriptomes from potato cyst nematodes, Globodera $\begin{array}{lll}\text { rostochiensis and G. pallida, A nature, } & \text { research. }\end{array}$ http://dx.doi.org/10.1038/s41598-017-03871-x.

Fleming, C.C., Turner, S.J., Powers, T.O. and Szalanskj, A.L. (1998) Diagnostics of cyst nematodes: use of the polymerase chain reaction to determine species and estimate population levels, Aspects of Applied Biology. 52:375-382. http://dx.doi.org/10.1.1.487.620.

Goellner, M., Smant, G., De Boer, J., Baum, T. and Davis, E.L. (2000) Isolation of beta-1, 4-endoglucanase genes from Globodera tabacum and their expression during parasitism. Nematol. 32:154.

Gurr, S.J., Mcpherson, M.J., Scollan, C., Atkinson, H.J. and Bowles, D.J. (1991) Gene expression in nematode-infected plant roots, Mol Gen Genet. 226:361-366. http://dx.doi.org/10.1007/BF00260647.

Hamamouch, N., Chunying, L.I., Hewezi, T., Baum, T.J., Mitchum, M.G., Hussey, R.S., Vodkin, L.O. and Davis, E.L. (2012). The interaction of the nove $30 \mathrm{C} 02$ cyst nematode effector protein with a plant $\beta-1,3$-endoglucanase may suppress host defence to promote parasitism, Experimental Botany. 10:36833696. http://dx.doi.org/10.1093/jxb/ers058.

Hamamouch, N., Chunying, L.I., Seo, P.J., Park, C.M. and Davis, E.L. (2011) Expression of Arabidopsis pathogenesis-related genes during nematode infection, Molecular Plant Pathology. 4:355-364. http://dx.doi.org/10.1093/jxb/ers058.

Hammond, K.E., Atkinson, H.J. and Bowles, D.J. (1989). Systemic accumulation of novel proteins in the apoplast of the leaves of potato plants following root invasion by the cyst-nematode Globodera rostochiensis, Physiol. MOI. Plant Pathol. 35:495-506. http://dx.doi.org/10.1016/0885-5765(89)90091-X.

Ibrahim, I.K.A., Handoo, Z.A. and Basyony, A.B.A. (2017). The cyst nematodes Heterodera and Globodera species in Egypt, Pakistan Journal of Nematology. 2:151-154. http://dx.doi.org/10.18681/pjn.v35.i02.p151-154.
Kombrink, E., Schroder, M. and Hahlbrock, K. (1988). Several pathogenesisrelated proteins in potato are 1,3-beta-glucanases and chitinases, PNAS USA 3:782-786. http://dx.doi.org/10.1073/pnas.85.3.782.

Kumari, C., Dutta, T.K., Banakar, P. and Rao, U. (2016). Comparing the defence-related gene expression changes upon root-knot nematode attack in susceptible versusresistant cultivars of rice, Scientific reports. 6:22846. http://dx.doi.org/10.1038/srep22846.

Li R. Rashotte, A.M., Singh, N.K., Weaver, D.B., Lawrence, K.S. and Locy, R.D. (2015). Integrated signaling networks in plant responses to sedentary endoparasitic nematodes: a perspective, Plant Cell Rep. 34:5-22 http://dx.doi.org/10.1007/s00299-014-1676-6.

Me'traux, J.P. (2001). Systemic acquired resistance and salicylic acid: current state of knowledge, Eur. J. Plant Pathol., 107:13-18 http://dx.doi.org/10.1023/A:1008763817367.

Niebel, A., Gheysen, G. and Van Montagu, M. (1994). Plant cyst nematode and plant root knot nematode interactions, Parasitology Today. http://dx.doi.org/10:424-430. 10.1016/0169-4758(94)90172-4.

Pratelli, J., Sutter, J.U. and Blatt, M.R. (2004). A new catch in the SNARE, Trends Plant Sci. 9:187-195. http://dx.doi.org/10.1016/j.tplants.2004.02.007.

Rahimi, S., Perry R.N. and Wright, D.J. (1993). Induction and detection of pathogenesis-related proteins in leaves and roots of potato plants infected with pathotypes of Globodera pallid, Fundam. appl. Nematol., 6:549-556.

Rashad, Y.M., Aseel, D.G. and Hafez, E.E. (2018). Antifungal potential and defense gene induction in maize against Rhizoctonia root rot by seed extract of Ammivisnaga (L.) Lam., Phytopathologia Mediterranea. 1:73-88. http://dx.doi.org/10.14601/Phytopathol Mediterr-21366.

Sattarzadeh, A., Achenbach, U., Lübeck, J., Strahwald, J., Tacke, E., Hofferbert, H.R., Rothsteyn, T. and Gebhardt, C. (2006). Single nucleotide polymorphism (SNP) genotyping as basis for developing a PCR-based marker highly diagnostic for potato varieties with high resistance to Globodera pallid pathotype Pa2/3, Mol Breeding. 18:301-312. http://dx.doi.org/10.1007/s11032-006-9026-1.

Shaikhaldein, H.O., Hoffmann, B. Alaraidh, I.A. and Aseel, D.G. (2018) Evaluation of extreme resistance genes of Potato virus $\mathrm{X}(\mathrm{R} \times 1$ and $\mathrm{Rx} 2)$ in different potato genotypes. Journal of Plant Diseases and Protection 125:251257. http://dx.doi.org/10.1007/s41348-018-0148-6. (

Shepherd, A.M. (1985). Extraction and estimation of cyst nematodes. In: J.F Southey, (Ed) Laboratory methods for work with plant and soil nematodes Ministry of Agriculture, Fisheries \& Food, London. 31-49. http://dx.doi.org/10.1371/journal.pone.0157017.

Shepherd, A.M. (1986). Extraction and estimation of cyst nematodes, In Laboratory methods for work with Plant and soil nematodes.31-49. http://dx.doi.org/10.1371/journal.pone.0157017.

Sijmons, P.C., Atkinson, H.J. and Wyss, U. (1994). Parasitic strategies of root nematodes and associated host cell responses, Annu. Rev. Phytopathol. 32:235259. http://dx.doi.org/10.1146/annurev.py.32.090194.001315.

Tamura, K., Dudley, J., Ne, M. and Kumar, S. (2207). MEGA4: Molecular Evolutionary Genetics Analysis (MEGA) software version 4.0, Mol. Biol. Evol., 24: 1596-1599. http://dx.doi.org/10.1093/molbev/msm092.

Van Eldik, G.J., Wingens, M., Ruiter, R.K., Van Herpen, M.M., Schrauwen, J.A and Wullems, G.J. (1996). Molecular analysis of a pistil-specific gene expressed in the stigma and stylar cortex of Solanum tuberosum, Plant Molecular Biology. 30:171-176. http://dx.doi.org/10.1007/BF00017811.

Wang, X., Meyers, D., Yan, Y., Baum, T., Smant, G., Hussey, R. Davis, E.L. (1999). In planta localization of a $\beta$-1, 4-endoglucanase secreted by Heterodera $\begin{array}{llll}\text { glycines, Mol. } & \text { Plant-Microbe } & \text { Interact. }\end{array}$ http://dx.doi.org/10.1094/MPMI.1999.12.1.64.

White, T.J., Bruns, T. and Lee, S. (1990). Amplification and direct sequencing of fungal ribosomal RNA genes for phylogenetics. In: Innis M.A., Gelfand D.H., Sninsky J.J., White T.J., editors. PCR protocols. A guide to methods and applications. San Diego: Academic Press; 315-22. http://dx.doi.org/10.1016/b978-0-12-372180-8.50042-1. 